\title{
Novel Strategies for Allergy Immunotherapy
}

\author{
William R. Reisacher • Andrea Wang
}

Published online: 2 February 2013

(c) Springer Science+Business Media New York 2013

\begin{abstract}
This article reviews the literature on allergen modifications and novel routes of delivery for antigen-specific immunotherapy for allergic disease. Allergen modifications include the use of recombinant proteins, combining antigens with infectious carrier proteins, peptide immunotherapy, and genetic vaccines containing the code for allergenic proteins. Novel routes of delivery include oral immunotherapy, intralymphatic immunotherapy, epicutaneous immunotherapy, and oral mucosal immunotherapy. Allergen depot preparations, such as biodegradable, injectable microspheres and sublingual tablets, have also been developed. Current research in immunotherapy for allergic disease has focused on improving efficacy and patient adherence to therapy, while minimizing the risks of serious adverse events.
\end{abstract}

Keywords Immunotherapy · Peptide - Allergy · Subcutaneous - Sublingual - Delivery · Antigens · Recombinant · Epitopes · Oral mucosa · Asthma · Rhinoconjunctivitis - Antigen-presenting cells

\section{Introduction}

Allergy, when combined with its comorbidities, is the commonest chronic disease in the USA [1]. Unlike avoidance strategies and medications, allergen-specific immunotherapy is the only known disease-modifying treatment for allergic rhinitis and asthma [2]. Allergen-specific

W. R. Reisacher $(\bowtie) \cdot$ A. Wang

Presbyterian Hospital/Weill Cornell Medical College, 1305 York

Avenue, 5th Floor, New York, NY 10021, USA

e-mail: wir2011@med.cornell.edu immunotherapy involves the regular administration of allergenic extracts, to which the patient is sensitive, at a certain dose for approximately $3-5$ years. When antigens interact with memory $\mathrm{T}$ cells, a downregulation of the allergic response occurs and the proallergic, T-helper cell type $2\left(\mathrm{~T}_{\mathrm{h}} 2\right)$ phenotype shifts towards the T-helper cell type $1\left(T_{h} 1\right)$ phenotype [3]. Increases in the levels of IL-10, interferon- $\gamma$, and transforming growth factor $\beta$ lead to decreased mast cell and eosinophil activation, and class switching results in downregulation of IgE production and increased $\mathrm{IgG}_{4}$ production [4]. Patients treated with allergenspecific immunotherapy benefit from long-term symptom relief, decreased need for medications, and overall improvement in quality of life [5]. Allergen-specific immunotherapy also reduces the risk of new sensitizations and decreases the risk of asthma development $[6,7]$.

Since allergen-specific immunotherapy was described by Noon [8] in 1911, the primary delivery method has been through the subcutaneous route. Although it is generally considered safe, there is a risk of systemic reaction, which ranges from 0.05 to $3.2 \%$ of injections [9]. Because of this, as well as the inconvenience of weekly physician visits, fear of needles, and discomfort from local reactions, alternative delivery routes have been sought. In 1998, the World Health Organization endorsed sublingual immunotherapy (SLIT) as an alternative to subcutaneous immunotherapy (SCIT) [10]. SLIT involves the placement of the same extract used in SCIT underneath the tongue once or twice daily. Because of its superior safety profile compared with SCIT, SLIT may be administered by the patient from home [11]. Over the past several years, additional modifications, both in the allergen delivered and in the route of delivery, have been investigated in order to improve the safety of, efficacy of, and adherence to immunotherapy. 


\section{Allergen Modifications}

\section{Recombinant Allergens}

Recombinant allergens are purified allergens made from allergen-encoding DNA. They were developed to improve standardization and quality control $[12 \bullet, 13]$. Recombinant wild-type allergens mimic the molecular and immunologic properties of natural allergens, and can produce large quantities of proteins, which are naturally in short supply, with consistent quality $[12 \bullet, 14]$. In addition, they can be produced as hybrid molecules that contain epitopes of several different allergens [15]. However, recombinant wild-type allergens share the same potential IgE-related side effects of natural allergens. Recombinant hypoallergens were developed with reduced allergic activity by methods such as introducing mutations into the allergen sequence, deleting sequences, oligomerization, and fragmentation, with an end result of affecting $\operatorname{IgE}$ binding, while leaving T-cell epitopes intact $[12 \bullet, 16]$.

Recombinant wild-type birch pollen and grass pollens have been developed and tested in clinical studies. Pauli et al. [17] showed SCIT with recombinant wild-type birch pollen (rBet $v 1)$ to be equally efficacious as that with commercial birch pollen extract and natural purified birch pollen allergen (nBet v 1). In this randomized, double-blind, placebo-controlled (DBPC) trial, 134 adults who had birch-pollen-induced rhinitis were randomized into four groups: commercial birch pollen extract, rBet $\mathrm{v} 1$, nBet $\mathrm{v} 1$, and placebo. Treatment consisted of 12 weekly injections followed by monthly maintenance injections for 2 years. There was a $59 \%$ reduction in disease severity in patients treated with birch pollen extract and a $57 \%$ reduction in disease severity in patients treated with $\mathrm{r}$ Bet $\mathrm{v} 1$ and $\mathrm{n}$ Bet $\mathrm{v} 1$ compared with placebo. Active treatment induced statistically significant increases in the levels of $\operatorname{IgG}_{1}, \operatorname{IgG}_{2}$ and $\operatorname{IgG}_{4}$ Bet $\mathrm{v} 1$ specific antibodies, which were higher in the rBet $v 1$ group than in the birch pollen and nBet $v 1$ groups. Wild-type rBet $v 1$ is also being studied in a phase III SLIT trial with a dissolving tablet (Oralair Birch) [18, 19].

A mixture of five recombinant grass pollen allergens (rPhl p 1, rPhl p 2, rPhl p 5a, rPhl p 5b, and rPhl p 6) has been studied in a randomized, DBPC study [20]. Sixty-two adults were randomized into two groups receiving either the recombinant grass pollen allergen mixture or placebo via SCIT for 20 months. Of those who completed treatment, there was a $39 \%$ reduction in disease severity in actively treated patients compared with placebo. Actively treated patients had a statistically significant increase in the levels of allergen-specific $\mathrm{IgG}_{1}$ and $\mathrm{IgG}_{4}$ antibodies, and a significant decrease in allergen-specific IgE levels. However, seven of the 29 actively treated patients had systemic side effects, such as urticaria and asthma exacerbation.
Molecularly modified derivatives of recombinant, hypoallergenic birch pollen (Bet $v$ 1) have been developed either by expressing three copies of the gene to produce a trimer or by cleaving the gene to create two recombinant peptides. Both the recombinant Bet $\mathrm{v} 1$ trimer and fragments have been shown to be 100 times less allergenic by skin testing, while maintaining T-cell reactivity [21]. In a DBPC study, 124 subjects were randomized into three groups receiving placebo, recombinant Bet $\mathrm{v} 1$ trimer, or recombinant Bet $\mathrm{v} 1$ fragments. There were a high number of dropouts, and the results showed a trend towards improved symptoms, but did not show statistical significance in the combined symptom medication score. There were strong allergen-specific $\operatorname{IgG}_{1}$ and $\mathrm{IgG}_{4}$ responses in the treatment groups. A folding variant of hypoallergenic birch pollen, rBet v1-FV, has also been developed [22], with a recently completed multicenter, randomized DBPC study [23]. Clinical trials are ongoing using recombinant allergens for peach, crustaceans, dust mites, and nickel.

\section{Peptide Therapy}

Prior to class switching, the exogenous antigen is broken down into peptides within the antigen-presenting cell (APC). These peptides are presented on the APC surface by MHC class II molecules. Allergen-specific T cells recognize the T-cell epitope in the peptide, which initiates the secretion of $T_{h} 2$ cytokines, leading to production of allergen-specific IgE by B cells. This allergen-specific IgE then binds to IgE receptors on the surfaces of mast cells and basophils. IgE antibodies on the mast cell cross-link with a B-cell epitope on the allergen, which causes degranulation and release of inflammatory mediators, resulting in the clinical symptoms of allergy [24].

In peptide immunotherapy, synthetic peptides, which are a fraction of the size of the allergen, contain T-cell epitopes to engage the $T$ cells, leading to tolerance while eliminating the B-cell epitopes to avoid cross-linking of IgE. When $\mathrm{T}$-cell epitopes are presented to $\mathrm{T}$ cells by nonprofessional APCs (such as epithelial or endothelial cells) in a noninflammatory condition, antigen-specific tolerance occurs [25]. In vitro studies have shown that regulatory antigenspecific $\mathrm{T}$ cells suppress antigen-specific $\mathrm{T}$-cell proliferation, induced by IL-10, which downregulates the $T_{h} 2$ response to allergens [24, 25]. Like recombinant allergens, synthetic peptides can be produced in a standardized fashion ensuring quality and consistency [26].

Clinical studies of peptide immunotherapy have focused on cat and bee venom allergies [27-29, 30• 31, 32]. Early studies used T-cell lines from cat-allergic subjects to map T-cell epitopes for Fel d 1, the principal allergen of cat dander, to create two peptides of 27 amino acids each that contained multiple immunodominant T-cell epitopes 
(Allervax ${ }^{\circledR}$ Cat). In a multicenter, DBPC study of catallergic patients who were chronically exposed to cats or in whom SCIT had failed, 133 subjects received placebo, low-dose therapy, or high-dose therapy [27]. All patients treated with Allervax ${ }^{\circledR}$ Cat reported an improvement in cat tolerance, whereas pulmonary function improved only in the high-dose group. Twelve patients reported earlyonset allergic symptoms, likely secondary to IgE crosslinking, with three patients requiring epinephrine for treatment of systemic symptoms. Late-phase reactions, which are T-cell-mediated, occurred after $30 \mathrm{~min}$ but within $24 \mathrm{~h}$ more commonly, occurring twice as often in the patients treated with Allervax ${ }^{\circledR}$ Cat as in the patients treated with placebo.

Subsequently, smaller peptides, including a mixture of 12 peptides, each 16-17 amino acids in length, have been investigated to avoid the possibility of early-phase reactions [28]. Most recently, a seven-peptide vaccine (ToleroMune Cat or Cat-PAD) from Fel d 1 has been created by analyzing MHC binding in the previously mentioned 12-peptide mixture, and eliminating those peptides that did not bind to a panel of common HLA-DR molecules [29, 30•]. This new vaccine also incorporated thioglycerol, which prevents dimerization of peptides containing cysteine residues, thereby decreasing the chance of IgE crosslinking. In a randomized DBPC parallel-group clinical trial, 202 subjects were exposed to cat allergen before and after treatment with either placebo, $6 \mathrm{nmol}$ Cat-PAD every 4 weeks for 12 weeks (four injections), or $3 \mathrm{nmol} \mathrm{Cat-}$ PAD every 2 weeks for 12 weeks (eight injections) [30॰]. There was a significant reduction in the total rhinoconjunctivitis symptom scores after allergen exposure with the 6-nmol dose compared with the 3-nmol dose and placebo. The treatment effect persisted for 1 year after the start of treatment. One limitation of peptide therapy is the degree of polymorphism in a population, producing a large diversity in T-cell peptide epitopes and making it challenging to develop small, specific synthetic peptides.

\section{Adjuvants and Coupled Allergens}

Allergen-specific immunotherapy has traditionally used aluminum hydroxide as an adjuvant. Developments have been made to couple allergens with immunostimulatory molecules, often derived from viruses and bacteria, to further activate and modulate the innate immune system [33-37].

The innate immune system provides a nonspecific first line of defense, by recognizing pathogen-associated molecular patterns that are not present on host cells. One example is unmethylated cytosine-guanine dinucleotides $(\mathrm{CpG})$, which are found in bacterial DNA. CpG or CpG-ODN (synthetic oligodeoxynucleotides that contain $\mathrm{CpG}$ motifs) is recognized by Toll-like receptor (TLR) 9, an innate pattern recognition receptor, on B cells, dendritic cells, and other cells, resulting in the induction of $\mathrm{T}_{\mathrm{h}} 1$ and regulatory $\mathrm{T}$ cells with suppression of the $\mathrm{T}_{\mathrm{h}} 2$ response [34]. A randomized, DBPC phase II trial in which 25 adults with ragweed allergy received either a vaccine consisting of $\mathrm{Amb}$ a 1, a ragweed-pollen antigen, conjugated to a CpGODN allergen immunostimulatory conjugate or placebo before the ragweed season, showed improved nasal symptom scores and overall quality of life scores in the actively treated group compared with the placebo-treated group during two ragweed seasons [35]. Although the phase III trial was discontinued when these results were not confirmed, $\mathrm{CpG}$ immunostimulatory sequences are still being included in the development of other vaccines, including DNA vaccines.

Other TLR ligands that have been shown to induce the $\mathrm{T}_{\mathrm{h}} 1$ pathway and inhibit the $\mathrm{T}_{\mathrm{h}} 2$ pathway include lipoproteins, polyinosinic-polycytidylic acid, and lipopolysaccharides [38]. Monophosphoryl lipid A, a derivative of lipid A from Salmonella Minnesota R595 lipopolysaccharide, is a TLR-4 agonist. Pollinex Quattro vaccines combine chemically modified grass, ragweed, or tree allergens with monophosphoryl lipid A [39]. Clinical trials in adults and children have shown symptom improvement [40-42]. Pollinex Quattro is available in Europe, and the FDA recently lifted a clinical hold, allowing a phase III study to proceed in the USA [43].

Other viral and bacterial proteins or by-products also have the ability to skew the immune system towards a $T_{h} 1$ dominated pathway. Both virus-like particles, which resemble viruses but do not contain viral genetic protein, and viral capsids have been studied. CYT003-QbG10 is an A-type CpG-ODN packaged into a virus-like particle without an allergen [44•]. In a randomized, double-blind phase IIb study, 299 patients with perennial allergic rhinoconjunctivitis caused by house dust mite (HDM) allergy received six weekly injections of low-dose CYT003QbG10, high-dose CYT003-QbG10, or placebo. The treatment was well tolerated, and symptoms and overall quality of life improved in patients treated with high-dose CYT003-QbG10 compared with placebo. Also, the highdose group tolerated a tenfold improvement on the conjunctival provocation test, whereas the placebo group experienced no change [44•].

Combination allergen-infectious disease vaccines, coupling an allergen with a viral capsid, represent an innovative direction in immunizing children against both common viral infections and allergens. A vaccine composed of viral capsid protein (VP1) of human rhinovirus and a peptide derived from major timothy grass pollen allergen ( $\mathrm{Phl} \mathrm{p} \mathrm{1)}$ has been studied in a mouse model, showing a VP1-specific 
$\mathrm{T}_{\mathrm{h}} 1$ response, inhibited basophil degranulation, and immunity to rhinovirus exposure [45].

Biodegradable microspheres, such as poly(D,L-lacticco-glycolic acid), can be used to encapsulate an allergen for delivery via injection or ingestion. The benefit of microsphere delivery is a controlled release of the allergen over a period of time, which may result in less frequent treatments, as well as avoiding the safety risks associated with subcutaneous bolus injections of an allergen [46].

\section{Genetic Vaccines}

DNA vaccines have been shown to produce an antigenspecific T-cell immune response, and have been extensively studied in the realm of antiviral and cancer therapy. Within the field of allergy, DNA vaccination has been shown in a mouse model to modulate $\operatorname{IgE}$ response and shift the immune system towards a $\mathrm{T}_{\mathrm{h}} 1$-dominated pattern, thereby limiting the clinical presentation of allergy [47, 48, 49•, 50].

The mechanism of DNA vaccination is in vivo transfection, whereby plasmid DNA encoding an allergen is injected into the skin or muscle. The DNA is then taken up by APCs, as well as non-APCs (epithelial cells, muscle cells), where it is transcribed and translated into the allergen. The endogenously produced allergen is presented on the APC surface by MHC class I and class II molecules, leading to antigen-specific $\mathrm{CD}^{+}$and $\mathrm{CD}^{+}$T-cell responses, in a $\mathrm{T}_{\mathrm{h}} 1$-biased manner. This results in secretion of interferon- $\gamma$, induction of cytotoxic $\mathrm{T}$ lymphocytes, B-cell proliferation, and class switching to IgG, which competes with IgE. Immune complexes of IgG and allergen also serve to activate APCs and amplify the immune response. In addition, the uptake of plasmid DNA and expression of foreign antigen may cause apoptosis in the transfected cell, which again contributes to $\mathrm{T}_{\mathrm{h}} 1$-biased immunity [47].

Genetic vaccination experiments have also used recombinant technology and peptide therapy research to produce hypoallergenic DNA vaccines. Theoretical risks associated with DNA vaccines include side effects from long-term, uncontrolled expression of the encoded antigen, possible generation of anti-DNA antibodies, autoimmunity, and inclusion of the DNA into the genome, causing potential oncogenic consequences [49•]. RNA vaccines, which degrade more quickly within the cell and cannot be incorporated within a genome, were developed to address these concerns. In a mouse model, RNA vaccines have been shown to induce $T_{h} 1$-weighted immune responses similar to those induced by DNA vaccines [51, 52].

\section{Novel Routes of Delivery}

\section{Oral Immunotherapy}

SCIT is not recommended for the treatment of food allergy because of a high rate of systemic reactions with peanut allergen injection [53]. Oral immunotherapy (OIT) has been shown to be a safer route for desensitization, with an increasing body of literature over the last 5 years. Peanut [54•, 55, 56], egg [57-59], and milk [60•, 61, 62] are the antigens which have been most studied.

One recent multicenter, DBPC trial examined 28 children with peanut allergy who received OIT with peanut flour or placebo over 1 year in three phases (initial escalation, buildup, and maintenance) [54•]. After 1 year of therapy, an oral food challenge was performed. Although three of 19 subjects receiving peanut OIT withdrew early because of adverse effects, the remaining 16 subjects were able to ingest a maximum cumulative dose of 5,000 mg (approximately 20 peanuts), compared with the nine patients receiving placebo, who ingested a median cumulative dose of $280 \mathrm{mg}$, or one peanut. The OIT patients also exhibited a decrease in skin reactivity, decreased $T_{h} 2$ cytokine production, and increases in the levels of peanutspecific $\mathrm{IgG}$ and $\mathrm{IgG}_{4}$.

Safety and permanent tolerance are the main limitations of OIT. Many of the clinical trials performed exclude subjects who have had anaphylactic reactions to the food [54•, 55-59, 60• 61, 62]. Side effects during immunotherapy, although usually mild, are largely unavoidable. Yu et al. [56] reported on the safety of peanut OIT, with $84 \%$ of all symptoms reported as mild, requiring no treatment or treatment with antihistamines. However, severe reactions do occur, often after exercising, bathing, OIT on an empty stomach, concurrent febrile illness, or poorly controlled asthma [54•, 55]. As such, OIT still requires periods of close observation or inpatient stay during periods of escalation.

Developments are currently being made to improve safety. OIT using extensively heated milk or egg in children with milk or egg allergies has been shown in clinical trials to be effective in increasing tolerance [63, 64]. Tolerance is defined as a permanent unresponsiveness to an allergen after therapy has been completed, whereas desensitization requires continued therapy to maintain unresponsiveness. Few studies have been able to demonstrate tolerance, especially for long periods of time. Keet et al. [60•] reported an open-label trial whereby 30 children with cow's milk allergy were randomized into three groups: SLIT alone, SLIT followed by OIT to a target of $2 \mathrm{~g}$ milk protein (OITA), or SLIT followed by OIT to a target of $1 \mathrm{~g}$ milk protein (OITB). After 60 weeks of maintenance therapy, one of ten patients in the 
SLIT-alone group, six of ten patients in the SLIT/OITB group, and eight of ten patients in the SLIT/OITA group were not reactive to challenge with $8 \mathrm{~g}$ of cow's milk protein. These 15 patients were taken off therapy and after 1 week were given another food challenge. Two patients (from the SLIT/OITB group) failed the food challenge. The 13 patients who passed underwent another food challenge 5 weeks later, where four patients failed (one from the SLIT/OITB group and three from the SLIT/OITA group). This demonstrates that although SLIT and OIT showed efficacy with desensitization to cow's milk allergy, tolerance after therapy was not easily achieved, and further studies with longer periods of follow-up are necessary.

\section{Intralymphatic Immunotherapy}

Intralymphatic injections of anticancer therapy and antiviral vaccines have demonstrated strong immune responses to small amounts of antigen in animal models and humans [65-67]. The adoption of intralymphatic injection in allergen-specific immunotherapy has many potential benefits, including enhanced immunogenicity by direct injection, decreased number of systemic side effects, reduction in the treatment dose, and a decrease in the overall length of therapy [65].

In an open-label study, 165 patients with grass-polleninduced rhinoconjunctivitis were randomized to receive either SCIT with pollen extract over 3 years or three intralymphatic injections over 2 months. Intralymphatic immunotherapy (ILIT) was found to induce allergen tolerance faster than SCIT (4 months vs 1 year) and was found to cause fewer allergic side effects [68]. ILITinduced tolerance was also found to be as long-lasting as SCIT.

More recently, a randomized, DBPC trial compared ILIT with a modified recombinant major cat dander allergen (MAT-Fel d 1) with ILIT with placebo in 20 catallergic patients [69•]. MAT-Fel d 1 was modified to enhance presentation through the MHC class II pathway. Subjects received three injections of MAT-Fel d 1 or placebo over 3 months. ILIT with MAT-Fel d 1 increased nasal tolerance by 74 -fold, compared with placebo, which increased nasal tolerance by threefold. ILIT with MAT-Fel d 1 also stimulated regulatory $\mathrm{T}$-cell responses and increased the levels of cat-dander-specific $\mathrm{IgG}_{4}$ [69•].

\section{Epicutaneous Immunotherapy}

Epicutaneous immunotherapy (EPIT), or transcutaneous immunotherapy, offers a promising noninvasive route of allergen delivery [65]. The repeated application of adhesive skin patches effectively strips the skin of the stratum corneum, allowing penetration of the allergen into the epidermis $[65,70]$. This process also stimulates the release of proinflammatory cytokines by keratinocytes [71].

Senti et al. [72] reported a DBPC trial of 132 patients with grass pollen rhinoconjunctivitis, randomized to receive six weekly patches of placebo or low, intermediate, or high doses of allergen. Only the high-dose group showed a statistically significant reduction in hay fever symptoms of $30 \%$ in the first year and of $24 \%$ in the second year of follow-up. The higher dose was also associated with more adverse events, most commonly pruritus, erythema, and eczema at the site of the patch. There was also an $8.3 \%$ dropout rate because of systemic side effects.

Viaskin ${ }^{\circledR}$ is an epicutaneous delivery system that allows delivery of allergen into the epidermis without disrupting the stratum corneum [73]. The allergen is placed on a polyethylene membrane within an occlusive chamber that adheres to the skin. Perspiration releases the allergens, which diffuse through the epidermis to the APCs [73]. EPIT testing with pollen, HDM, ovalbumin, and peanut in a mouse model has demonstrated efficacy similar to that of SCIT [73]. In a study of 18 children with cow's milk allergy randomized to receive either active epicutaneous delivery with cow's milk powder or placebo, safety was demonstrated, with a trend towards clinical efficacy [74]. A multicenter, DBPC phase II study (NCT01197053) of EPIT in children with peanut allergy is currently under way [75].

\section{Allergy Immunotherapy Tablets}

Over the past decade, tablets containing freeze-dried allergenic proteins have appeared on the market. They are designed to disintegrate immediately when interacting with saliva in the sublingual space, thus exposing amino acids and polypeptides to Langerhans cells in the oral mucosa. The potential advantages of allergy immunotherapy tablets (AIT) over liquid SLIT preparations are the standardization of dosing and easier application of extract proteins to the mucosa. The first AIT was Grazax ${ }^{\circledR}$, developed in Europe by ALK-Abello (Horsholm, Denmark). In Europe, grass pollen is associated with over $50 \%$ of allergic rhinitis cases, being the commonest cause of respiratory allergy [76]. Grazax ${ }^{\circledR}$ contains 75,000 standardized quality tablet (SQ-T) units, which corresponds to approximately $15 \mu \mathrm{g}$ of the major antigen, Phleum pratense, and has demonstrated the best efficacy-to-tolerability ratio [77, 78].

Several multicenter, randomized, DBPC phase II and phase III trials have been completed demonstrating the safety and efficacy of AIT with Grazax ${ }^{\circledR}$ for seasonal allergic rhinoconjunctivitis in both preseasonal and coseasonal therapy, as well as with 3 years of continuous use $\left[79,80^{\bullet}\right]$ Grazax $^{\circledR}$ and a five-grass-pollen tablet (Oralair, Stallergenes, Antony, France) have demonstrated reductions in symptom scores of $37 \%$ and reductions in 
medication scores of $53 \%$ [81]. Significant symptom reduction scores have been reported in pediatric patients with grass-pollen-induced rhinoconjunctivitis [82••]. With use of a timothy grass tablet containing 75,000 standardized quality tablet units developed by Schering-Plough/ Merck, similar safety and efficacy for grass AIT was determined for North American children, adolescents, and adults who began treatment 16 weeks before the season started and continued treatment during the season [83•, 84•]. Local side effects, such as oral itching, mild swelling, and throat irritation, were common, particularly at the beginning of therapy. However, postmarketing surveillance data for Grazax $^{\circledR}$ demonstrated a rate of systemic reactions of 0.7 per 1,000 treatment years [85]. Asthma prevention trials are also currently under way for grass AIT.

Other AIT products currently being developed include HDM, ragweed, birch pollen, Japanese cedar, and cat dander. An HDM tablet is currently in phase III trials. Two studies performed on children, adolescents, and adults with allergic rhinoconjunctivitis and asthma demonstrated that the HDM tablet was well tolerated [86, 87]. The side effects were similar to those resulting from grass AIT, but severer adverse reactions, such as vomiting, mouth edema, and throat tightness, were also noted. In addition, treatment with dust AIT at the highest dose for 40 weeks led to a significant reduction in inhaled corticosteroid use after 1 year. A similar tolerability profile was noted for a ragweed tablet, which is currently in phase III trials [88••].

Oral mucosal immunotherapy is an attractive alternative because of the higher density of Langerhans cells in the vestibule and gingiva compared with the sublingual mucosa [89]. Current testing is under way on toothpaste preparations containing oak, birch, and cat allergens (AllerDent, Allovate, New York, NY, USA).

\section{Conclusions}

Therapeutic approaches to immunotherapy are primarily aimed at reducing the risk of adverse events, while maintaining or improving immunogenicity and ultimately achieving tolerance. Several different antigen modifications are being developed along with innovative routes of delivery. Although this review has highlighted separate approaches, the combination of these approaches is at the forefront of allergen-specific immunotherapy research today.

Disclosure William R. Reisacher has been a consultant for or has had an advisory role with TEVA, Thermo Fisher, and Allovate.

\section{References}

Papers of particular interest, published recently, have been highlighted as:

- Of importance

- Of major importance

1. NCHS. Prevalence of selected chronic conditions. Hyattsville: National Center for Health Statistics; 1994.

2. Canonnica GW, Bousquet J, Casale T, et al. Sub-lingual immunotherapy: world allergy organization position paper 2009. Allergy. 2009;64(Suppl 91):1-59.

3. Maggi E. T cell responses induced by allergen-specific immunotherapy. Clin Exp Immunol. 2010;161(1):10-8.

4. Scadding G, Durham S. Mechanisms of sublingual immunotherapy. J Asthma. 2009;46:322-34.

5. Durham SR, Walker SM, Varga EM, et al. Long-term clinical efficacy of grass-pollen immunotherapy. N Engl J Med. 1999; 341:468-75.

6. Silvestri M, Rossi GA, Cozzani S, et al. Age-dependent tendency to become sensitized to other classes of aeroallergens in atopic asthmatic children. Ann Allergy Asthma Immunol. 1999;83: $335-40$.

7. Jacobsen L, Niggemann B, Dreborg S, et al. Specific immunotherapy has long-term preventative effect of seasonal and perennial asthma: 10-year follow-up on the PAT study. Allergy. 2007;62:943-8.

8. Noon L. Prophylactic inoculation against hay fever. Lancet. 1911;1:1572-3.

9. Seiberling K, Hiebert J, Nyirady J, et al. Cost of allergy immunotherapy: sublingual vs subcutaneous administration. Int Forum Allergy Rhinol. 2012;00:1-5.

10. Bousquet J, Lockey R, Malling HJ, et al. Allergen immunotherapy: therapeutic vaccines for allergic disease. world health organization. American academy of allergy, asthma and immunology. Ann Allergy Asthma Immunol. 1998;81:401-5.

11. Cox L. Sublingual immunotherapy and allergic rhinitis. Curr Allergy Asthma Rep. 2008;8:102-10.

12. - Valenta R, Niespondziana K, Focke-Tejkl M, et al. Recombinant allergens: what does the future hold? J Allergy Clin Immunol. 2011; 127:860-4. This is a review of the current trials of recombinant allergens.

13. Focke M, Swoboda I, Marth K, et al. Developments in allergenspecific immunotherapy: from allergen extracts to allergy vaccines bypassing allergen-specific immunoglobulin $\mathrm{E}$ and $\mathrm{T}$ cell reactivity. Clin Exp Allergy. 2010;40:385-97.

14. Valenta R, Ferreira F, Focke-Tejkl M, et al. From allergen genes to allergy vaccines. Annu Rev Immunol. 2010;28:211-41.

15. Linhart B, Hartl A, Jahn-Schmid B, et al. A hybrid molecule resembling the epitope spectrum of grass pollen for allergy vaccination. J Allergy Clin Immunol. 2005;115:1010-6.

16. Valenta R, Campana $\mathrm{R}$, Marth $\mathrm{K}$, et al. Allergen-specific immunotherapy: from therapeutic vaccines to prophylactic approaches. J Intern Med. 2012;272:144-57.

17. Pauli G, Larsen TH, Rak S, et al. Efficacy of recombinant birch pollen vaccine for the treatment of birch-allergic rhinoconjunctivitis. J Allergy Clin Immunol. 2008;122:951-60.

18. Winther L, Poulsen LK, Robin B, et al. Safety and tolerability of recombinant bet $\mathrm{v} 1$ (rBet $\mathrm{v} 1$ ) tablets in sublingual immunotherapy (SLIT). J Allergy Clin Immunol. 2009;123:S215.

19. Larenas-Linnemann D. Oralair Birch, a recombinant major birch pollen allergen tablet for sublingual immunotherapy of allergic rhinitis caused by birch pollen. Curr Opin Investig Drugs. 2010;11:586-96. 
20. Jutel M, Jaeger L, Suck R, et al. Allergen-specific immunotherapy with recombinant grass pollen allergens. J Allergy Clin Immunol. 2005;116:608-13.

21. Pauli G, Purohit A, Oster JP, et al. Comparison of genetically engineered hypoallergenic $\mathrm{rBet} \mathrm{v} 1$ derivatives with $\mathrm{rBet} \mathrm{v} 1$ wild-type by skin prick and intradermal testing: results obtained in a French population. Clin Exp Allergy. 2000;30:1076-84.

22. Kahlert H, Suck R, Weber B, et al. Characterization of a hypoallergenic recombinant Bet $\mathrm{v} 1$ variant as a candidate for allergenspecific immunotherapy. Int Arch Allergy Immunol. 2008;145: 193-206.

23. Campana R, Vrtala S, Maderegger B, et al. Hypoallergenic derivatives of the major birch pollen allergen Bet $\mathrm{v} 1$ obtained by rational sequence reassembly. J Allergy Clin Immunol. 2010;126: 1024-31.

24. Tanabe S. Epitope peptides and immunotherapy. Curr Protein Pept Sci. 2007;8:109-18.

25. Moldaver D, Larche M. Immunotherapy with peptides. Allergy. 2011;66:784-91.

26. Larche M. T cell epitope-based allergy vaccines. Curr Top Microbiol Immunol. 2011;352:107-19.

27. Norman PS, Ohman JL, Long AA, et al. Treatment of cat allergy with T-cell reactive peptides. Am J Respir Crit Care Med. 1996;154:1623-8.

28. Oldfield WL, Larche M, Kay AB. Effect of T-cell peptides derived from Fel d 1 on allergic reactions and cytokine production in patients sensitive to cats: a randomized controlled trial. Lancet. 2002;360:47-53.

29. Worm M, Lee HH, Kleine-Tebbe J, et al. Development and preliminary clinical evaluation of a peptide immunotherapy vaccine for cat allergy. J Allergy Clin Immunol. 2011;127:89-97.

30. - Patel D, Couroux P, Hickey P, et al. Fel d 1-derived peptide antigen desensitization shows a persistent treatment effect 1 year after the start of dosing: a randomized, placebo-controlled study. J Allergy Clin Immunol. 2013;131:103-9.e7. This is the first study demonstrating prolonged clinical efficacy of peptide therapy.

31. Muller U, Akdis CA, Fricker M, et al. Successful immunotherapy with T-cell epitope peptides of bee venom phospholipase A2 induces specific T-cell anergy in patients allergic to bee venom. J Allergy Clin Immunol. 1998;101:747-54.

32. Texier C, Pouvelle S, Busson M. HLA-DR restricted peptide candidates for bee venom immunotherapy. J Immunol. 2000;164: 3177-84.

33. Pfaar O, Cazan D, Klimek L, et al. Adjuvants for immunotherapy. Allergy Clin Immunol. 2012;12:648-57.

34. Fonseca DE, Kline JN. Use of CpG oligonucleotides in treatment of asthma and allergic disease. Adv Drug Deliv Rev. 2009;61:256-62.

35. Creticos PS, Schroeder JT, Hamilton RG, et al. Immunotherapy with a ragweed-toll-like receptor 9 agonist for vaccine for allergic rhinitis. N Engl J Med. 2006;355:1445-55.

36. Edlmayr J, Niespodziana K, Focke-Tejkl M. Allergen-specific immunotherapy: towards combination vaccines for allergic and infectious diseases. Curr Top Microbiol Immunol. 2011;352: 121-40.

37. Kundig TM, Senti G, Schnetzler G, et al. Der p 1 peptide on virus-like particles is safe and highly immunogenic in healthy adults. J Allergy Clin Immunol. 2006;117:1470-6.

38. Johansen P, Senti G, Martinez GJM. Toll-like receptor ligands as adjuvants in allergen-specific immunotherapy. Clin Exp Allergy. 2005;25:1591-8.

39. Gawchik SM, Saccar CL. Pollinex Quattro Tree: allergy vaccine. Expert Opin Biol Ther. 2009;9:377-82.

40. Drachenberg KJ, Wheeler AW, Stuebner P, et al. A well-tolerated grass pollen-specific allergy vaccine containing a novel adjuvant, monophosphoryl lipid A, reduces allergic symptoms after only four preseasonal injections. Allergy. 2001;56:498-505.

41. Drachenberg KJ, Heinzkill M, Urban E. Short-term immunotherapy with tree pollen allergoids and the adjuvant monophosphoryl lipid A: results from a multicenter, placebo-controlled, randomized, double-blind study. Allergologie. 2002;25:4465-74.

42. Drachenberg KJ, Proll S, Urban E, et al. Short-term immunotherapy using an allergy vaccine adjuvanted with monophosphoryl lipid A: a post marketing surveillance study. Int Rev Allergol Clin Immunol. 2002;8:219-23.

43. REG-Allergy Therapeutics-FDA clinical hold lifted. http:// www.reuters.com/article/2012/08/03/idUS50091+03-Aug-2012+ RNS20120803. Accessed Nov 2012.

44. - Klimek L, Wilers J, Hammann-Haenni A, et al. Assessment of clinical efficacy of CYT003-QbG10 in patients with allergic rhinoconjunctivitis: a phase IIb study. Clin Exp Allergy. 2011;41:1305-12. This is a phase IIb study demonstrating clinical efficacy of a TLR ligand adjuvant.

45. Edlymayr J, Niespodziana K, Linhart B, et al. A combination vaccine for allergy and rhinovirus infections based on rhinovirusderived surface protein VP1 and a nonallergenic peptide of the major timothy grass pollen allergen Phl p 1. J Immunol. 2009; 182:6298-306.

46. Reisacher WR, Liotta D. The use of poly(D,L-lactic-co-glycolic) acid microspheres in the treatment of allergic disease. Curr Opin Otolaryngol Head Neck Surg. 2011;19:188-92.

47. Weiss R, Scheiblhofer $S$, Gabler M, et al. Is genetic vaccination against allergy possible? Int Arch Allergy Immunol. 2006;139:332-45.

48. Chua KY, Huangfu T, Liew LN, et al. DNA vaccines and allergic diseases. Clin Exp Pharmacol Physiol. 2006;33:546-50.

49. - Weiss R, Scheiblhofer S, Rosler E, et al. DNA and RNA vaccines for prophylactic and therapeutic treatment of type I allergy. In: Thalhamer J, Weiss R, Scheiblhofer S, editors. Gene vaccines. Vienna: Springer; 2012, p. 247-263. This is a thorough review of the progress and challenges in DNA/RNA vaccines in the treatment of allergy.

50. Huang $\mathrm{CF}$, Chu $\mathrm{CH}$, Wu $\mathrm{CC}$, et al. Induction of specific Th1 responses and suppression of IgE antibody formation by vaccination with plasmid DNA encoding Cyn d 1. Int Arch Allergy Immunol. 2012;158:142-50.

51. Roesler E, Weiss R, Weinberger EE, et al. Immunize and disappear-safety-optimized mRNA vaccination with a panel of 29 allergens. J Allergy Clin Immunol. 2009;124:1070-7.

52. Weiss R, Scheiblhofer S, Roseler E. Prophylactic mRNA vaccination against allergy. Curr Opin Allergy Clin Immunol. 2010;10:567-74

53. Nelson HS, Lahr J, Rule R, et al. Treatment of anaphylactic sensitivity to peanuts by immunotherapy with injections of aqueous peanut extract. J Allergy Clin Immunol. 1997;99:744-51.

54. • Varsney P, Jones SM, Scurlock AM, et al. A randomized controlled study of peanut oral immunotherapy: clinical desensitization and modulation of the allergic response. J Allergy Clin Immunol. 2011;127:654-660. This is one of the larger studies demonstrating clinical efficacy of peanut OIT.

55. Blumchen K, Ulbricht $\mathrm{H}$, Staden U, et al. Oral peanut immunotherapy in children with peanut anaphylaxis. J Allergy Clin Immunol. 2010;126:83-91.

56. Yu GP, Weldon B, Neale-May S. The safety of peanut oral immunotherapy in peanut-allergic subjects in a single-center trial. Int Arch Allergy Immunol. 2012;159:179-82.

57. Burks AW, Jones SM, Wood RA, et al. Oral immunotherapy for treatment of egg allergy in children. N Engl J Med. 2012;367: 233-43.

58. Buchanan AD, Green TD, Jones SM, et al. Egg oral immunotherapy in nonanaphylactic children with egg allergy. J Allergy Clin Immunol. 2007;119:199-205. 
59. Lemon-Mule H, Sampson HA, Sicherer SH, et al. Immunologic changes in children with egg allergy ingesting extensively heated egg. J Allergy Clin Immunol. 2008;122:977-83.

60. - Keet CA, Frischmeyer-Guerrerio PA, Thyagarajan A, et al. The safety and efficacy of sublingual and oral immunotherapy for milk allergy. J Allergy Clin Immunol. 2012;129:448-455. This is one of the few studies to look at long-term tolerance to OIT.

61. Skripak JM, Nash SD, Rowley H, et al. A randomized, doubleblind, placebo-controlled study of milk oral immunotherapy for cow's milk allergy. J Allergy Clin Immunol. 2008;122:1154-60.

62. Longo G, Barbi E, Berti I, et al. Specific oral tolerance induction in children with very severe cow's milk-induced reactions. J Allergy Clin Immunol. 2008;121:343-7.

63. Urisu A, Tanaka K, Ogura K, et al. New approach for improving the safety of oral immunotherapy for food allergy. Clin Exp Allergy. 2012;12:25-8.

64. Nowak-Wegrzyn A, Bloom KA, Sicherer SH, et al. Tolerance to extensively heated milk in children with cows' milk allergy. J Allergy Clin Immunol. 2008;122:342-7.

65. Von Moos S, Kundig TM, Senti G. Novel administration routes for allergen-specific immunotherapy: a review of intralymphatic and epicutaneous allergen-specific immunotherapy. Immunol Allergy Clin N Am. 2011;31:391-406.

66. Juillard GJ, Boyer PJ, Yamashiro CH. A phase I study of active specific intralymphatic immunotherapy. Cancer. 1978;41:2215-25.

67. Senti G, Johanse P, Kundig TM. Intralymphatic immunotherapy: from rationale to human applications. Curr Top Microbiol Immunol. 2011;352:71-84.

68. Senti G, Senti G, Prinz VBM, Erdmann I, Markus R, McCormack $\mathrm{SJ}$, et al. Intralymphatic allergen administration renders specific immunotherapy faster and safer: a randomized controlled trial. Proc Natl Acad Sci USA. 2008;105:17908-12.

69. - Senti G, Crameri R, Kuster D, et al. Intralymphatic immunotherapy for cat allergy induces tolerance after only 3 injections. J Allergy Clin Immunol. 2012;129:1290-6. This is the first clinical study of ILIT with MAT-Fel d 1 .

70. Dickel H, Goulioumis A, Gambichler T, et al. Standardized tape stripping: a practical and reproducible protocol to uniformly reduce the stratum corneum. Skin Pharmacol Physiol. 2010;23: 239-65.

71. Nickoloff BJ, Naidu Y. Perturbation of epidermal barrier function correlates with initiation of cytokine cascade in human skin. J Am Acad Dermatol. 1994;30:535-46.

72. Senti G, von Moos S, Tay F. Epicutaneous allergen-specific immunotherapy ameliorates grass pollen-induced rhinoconjunctivitis: a double-blind, placebo-controlled dose escalation study. J Allergy Clin Immunol. 2012;129:128-35.

73. Mondoulet L, Dioszeghy V, Ligouis M. Epicutaneous immunotherapy on intact skin using a new delivery system in a murine model of allergy. Clin Exp Allergy. 2010;40:659-67.

74. Dupont C, Kalach N, Soulaines P. Cow's milk epicutaneous immunotherapy in children: a pilot trial of safety, acceptability, and impact on allergic reactivity. J Allergy Clin Immunol. 2010;125:1165-7.

75. ClinicalTrials.gov. Epicutaneous immunotherapy in peanut allergy in children (ARACHILD). http://clinicaltrials.gov/ct2/show/ NCT01197053. Accessed Nov 2012.
76. Dahl R, Andersen P, Chivato T, et al. National prevalence of respiratory allergic disorders. Respir Med. 2004;98:398-403.

77. Malling HJ, Lund L, Ipsen H, et al. Safety and immunological changes during specific sublingual immunotherapy with SQ standardized grass allergen tablets. J Investig Allergol Clin Immunol. 2006;16:162-8.

78. Durham SR, Yang WH, Pedersen MR, et al. Sublingual oncedaily grass-pollen immunotherapy: a randomized controlled trial in seasonal allergic rhinoconjunctivitis. J Allergy Clin Immunol. 2006;117:802-9.

79. Dahl R, Knapp A, Colombo G, et al. Efficacy and safety of sublingual immunotherapy with grass allergen tablets for seasonal allergic rhinoconjunctivitis. J Allergy Clin Immunol. 2006; 118:434-40.

80. - Durham SR, Emminger W, Kapp A, et al. Long-term clinical efficacy in grass pollen-induced rhinoconjunctivitis after treatment with SQ-standardized grass allergy immunotherapy tablet. J Allergy Clin Immunol. 2010;125:131-138. This is one of the few studies focusing on the long-term benefits of AIT with continuous use.

81. Bachert C. Treatment of respiratory allergy with allergy immunotherapy tablets. Allergy. 2011;66(Suppl 95):57-9.

82. •- Bufe A, Eberle P, Granke-Beckmann E, et al. Safety and efficacy in children of an SQ-standardized grass allergen tablet for sublingual immunotherapy. J Allergy Clin Immunol. 2009;123:167-173. This is the first phase III trial conducted using grass tablets in pediatric patients.

83. - Blaiss M, Maloney J, Nolte H, et al. Efficacy and safety of timothy grass allergy immunotherapy tablets in North American children and adolescents. J Allergy Clin Immunol. 2011;127: 64-71. This is the first study of grass AIT in North American children and adolescents.

84. - Nelson HS, Nolte H, Creticos P, et al. Efficacy and safety of timothy grass allergy immunotherapy tablet treatment in North American adults. J Allergy Clin Immunol. 2011;127:72-80. This is the first study of grass AIT in North American adults.

85. Dige E, Fejerskov PA, Calderon M. Safety profile of ALK grass allergen immunotherapy tablet after launch. Allergy. 2009;64 (Suppl 90):AB1230.

86. Calderon M, Dige E, Groes L. A house dust mite allergen immunotherapy tablet suitable for further clinical development: results from the first phase I tolerability trial. Allergy. 2009;64 (Suppl 90):148.

87. Mosbech H, de Blay F, Deckelmann R, et al. Efficacy against asthma demonstrated for a house dust mite allergen immunotherapy tablet. Allergy. 2009;64(Suppl 90):184.

88. •• Nayak AS, Atiee GJ, Dige E, et al. Safety of ragweed sublingual allergy immunotherapy tablets in adults with allergic rhinoconjunctivitis. Allergy Asthma Proc. 2012;33:404-410. This is the first clinical study of ragweed AIT in North American adults.

89. Allam JP, Stojanovski G, Friedrichs N, et al. Distribution of Langerhans cells and mast cells within the human oral mucosa: new application sites of allergens in sublingual immunotherapy? Allergy. 2008;63:720-7. 